第66回日本内科学会講演会 (1969年)

\title{
シンポジウム 喘＼cjkstart息
}

\section{（8）予定発言 気管支喘息の心身医学}

九州大学医学部心療内科教授

池 見 西 次 郎

\section{SYMPOSIUM ON ASTHMA. PSYCHOSOMATIC ASPECTS \\ OF ASTHMATIC ATTACK}

Yujiro IKem, M.D.

Professor of Department of Psychosomatic Medicine, Kyushu University School of Medicine

気管支ぜえそくの発生や経過にたいする精神的 な因子の役割についての考察は，今日までのとこ 万，一般的に概念的，抽象的なるのが多く，臨床 の実際に直結しかねるららみがある。离こで今回 は，心理的因子ぶぜんそくの自他覚的な呼吸困難 に、どのような影響を持つものであるかを，二， 三の実験的, 臨床的観察をもとにして申し述べた い.

1.まず，心理的な処理が，呼吸困難の経過に 好影響を及ぼす機転として重要なものは，心身の 弛緩である。ぜえそく患者にみられる慢性の不安 緊張状態が，気管支の過敏性を高め，発作準備状 態を作り，一たん発生した発作を増悪せしめるこ とは，普通に考えられているところである。この 意味において，心身の弛緩をはかる療法（催眠療 法, 自律訓練法，精神安定薬など）が，呼吸困難 の治療に効果的となるわけである。

さらに教室では，患者の前胸部にimpedance flowmeterをあて，その振幅を測定することによ つて, 肺血流量の間接的な示標の一つとしている. これについては，動物に実験的な気胸を作ると， flowmeterの振幅が，明らかに抑制されることを 確かめている. 一般に, 心理的ストレスによつて, 喘鳴が和こつた時，振幅が減少し，気管支拡張
薬，心理療法などで，発作が軽快すると，振幅が 增高する傾向がみられる、教室で，ぜんそく患者 に自律訓練法を実施させた結果，これがらまく行 なえた例では振幅が增加した、また，二，三の症 例で, 自律訓練法によつて, 振幅が增高したとこ ろで，発作発現の自己暗示を与え，呼吸困難感を 訴えるにつれて，振幅が減少することも観察され ている。ささらに24例のぜんそく以外の患者や健康 者を催眠状態に導入して, impedance flowmeter による測定を行なつた結果，導入によつて，心身 のくつろぎがえられた18例のほとんど全例に振幅 の増加がみられた。

今日一般に, 催眠療法だけでは効果がないこ と，あつても一時的であることが指摘されてい る.それは，むしろ当然のことであつて，以上の よらな意味に打ける弛緩療法は，あくまで，補助 寮法の一つである。また暗示などによつてえられ た，一時的な弛緩だけでは目的を達せず，自律訓 練法などによつて，たえず，自己弛緩を深めてゆ くこと，心理療法による精神生活の一般的な安定 をはかることなどによつて有効に作用するものと 思われる。

次に，呼吸困難の発生における自己暗示的な条 件つけの果す役割を端的に示す実験を行なつた。 
対照液をハウスダストと暗示して，吸入させた だけで，1秒率の著明な低下をきたしたもの（7 例）八ウスダストを吸入させても，それはぜん そく薬だと暗示することによつて，発作の発生が 扣さえられたもの（7 例)，これら2種類の暗示 が，いずれる有効に作用したもの（3例）をあわ 世ると，被殷者（ぜんそく患者）23例中17例にお いて，暗示効果か陽性に認められた。しかも，八 ウスダストにたいする過敏性の明らかな8例中 6 例においても，暗示効果が現われた。

今日心理学的に知られていることは，催眠性卜 ランスなどのような, 心身の統一, 注意集中の状 態では，条件づけや，条件つけの修正が正常覚醒 時よりも，速やかにかつ強力に行なわれるという ことである.したがつて，上記の上うな自己暗示 的な条件づけを，上り有利な方向に修正せしめる ための催眠療法的な操作が，ぜんそく治療の有力 な武器の一つとなりらるわけである.

第 3 に, ぜんそくの経過に, 最も重大な意味をも つ心理的因子は，その療着態度や療着条件を左右 する患者の性格傾向や心理的環境である. 副腎皮
質ホルモン依存性のぜんそく患者で，内分泌学的 には，注注等しい条件下にある；19人の患者につ いて，ステロイドの離脱を試みた結果，次のよう な成績が党られた。離脱が比較的容易に運んだ群 と，離脱が困難であつた群について比較すると， 後者の方が性格的に依存性の強いものが多く， た，情緒不安定，社会的不適応，内向的な抑圧傾 向，心理的な環境の悪条件などす明らかに後者に 多くみられた，この成績は，副腎皮質ホルモンの 離脱にさいしても，患者の身体的条件のみなら ず，その性格，心理的な環境などについての合理 的な分析と処理が，いかに重要なるのであるかを 示啐するるのと思われる。

以上述べたような，心身の弛緩，条件づけの修 正，性格傾向や心理的環境の分析とその処理とい う，より具体的，かつ謙虚な立場から，心理的因 子にたいする正しい配慮を，ぜんそくの呼吸困難 の診断や処理に活用するとき，ぜんそくの心身医 学は，次第に実地臨床に定着してくるものと思方 れる。

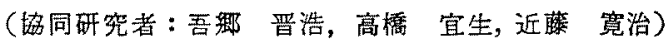

